\title{
Effect of Cobalt Supplementation During Late Gestation and Early Lactation on Milk and Serum Measures ${ }^{1}$
}

\author{
R. L. Kincaid ${ }^{\star 2}$ and M. T. Socha† \\ *Animal Sciences Department, Washington State University, Pullman 99164-6310 \\ †Zinpro Corporation Eden Prairie, MN 55344-7298
}

\begin{abstract}
Thirty-six multiparous cows were assigned to a study to determine the effects of dietary Co supplementation during late gestation and early lactation on concentrations of $\mathrm{Co}$ in serum and liver, vitamin $\mathrm{B}_{12}$ concentrations in serum and milk, and milk yield. Nonlactating cows received diets containing $0.15,0.89$, or $1.71 \mathrm{mg} /$ $\mathrm{kg}$ of $\mathrm{Co}$ (dry matter basis) from $55 \mathrm{~d}$ before parturition, and lactating cows received diets containing $0.19,0.57$, or $0.93 \mathrm{mg} / \mathrm{kg}$ of Co (dry matter basis) from parturition through $120 \mathrm{~d}$ postpartum. Serum vitamin $\mathrm{B}_{12}$ concentrations declined sharply in all cows between 55 and $20 \mathrm{~d}$ prepartum. Dietary Co supplementation tended to cause an increase in the concentration of vitamin $\mathrm{B}_{12}$ in colostrum and milk. Cobalt intake did not affect concentrations of Co in liver or serum, but increased the Co concentration of milk $(0.089,0.120$, and $0.130 \mu \mathrm{g}$ of $\mathrm{Co} / \mathrm{mL}$ ) at 120 days in milk. There was no effect of Co supplementation on dry matter intake or yield of milk and milk components. In conclusion, serum concentrations of vitamin $B_{12}$ are reduced in the early dry period, and added dietary Co may increase ruminal synthesis of vitamin $B_{12}$ as indicated by a tendency for increased vitamin $\mathrm{B}_{12}$ concentrations in colostrum and milk of cows supplemented with dietary Co.
\end{abstract}

Key words: cobalt, vitamin $\mathrm{B}_{12}$, cattle

\section{INTRODUCTION}

Ruminants require dietary Co for synthesis of vita$\min B_{12}$ in the rumen. The dietary requirement of dairy cows for Co is $0.11 \mathrm{mg} / \mathrm{kg}$ (NRC, 2001). However, ruminal synthesis of vitamin $\mathrm{B}_{12}$ is increased by higher concentrations of dietary Co (Mills, 1981). Using closed-

\footnotetext{
Received May 16, 2006.

Accepted November 11, 2006.

${ }^{1}$ Appreciation is expressed to Zinpro Corp., Eden Prairie, MN, for partial funding support for this study. The use of trade names and products in this publication does not imply endorsement or criticism of those products.

${ }^{2}$ Corresponding author: rkincaid@wsu.edu
}

system fermentors, Tiffany et al. (2006) recorded increased synthesis of vitamin $B_{12}$ as the Co concentration of the diet increased from 0.1 to $1.0 \mathrm{mg} / \mathrm{kg}$. Based upon performance and blood measures, the Co requirement for fattening cattle may be between 0.15 and $0.25 \mathrm{mg} /$ $\mathrm{kg}$ (Stangl et al., 2000a,b; Tiffany et al., 2003). However, ruminal synthesis of vitamin $\mathrm{B}_{12}$ was increased with dietary levels of $1.0 \mathrm{mg} / \mathrm{kg}$ of Co (Tiffany and Spears, 2002). In addition, a lower ratio of forage to concentrate in the diet is known to reduce ruminal synthesis of vitamin $\mathrm{B}_{12}$ (Walker and Elliot, 1972). More recently, Tiffany and Spears (2005) used fattening cattle to show an effect of grain source in the diet on ruminal synthesis of vitamin $B_{12}$ with greater response to Co supplementation when corn was the grain source compared with barley.

Secretion of $B_{12}$ into milk is a drain on maternal reserves of $B_{12}$; consequently, serum and liver $B_{12}$ concentrations are reduced in early lactation (Elliot et al., 1965; Wilson et al., 1967). Girard and Matte (2005) reported that cows given weekly i.m. injections of 10 $\mathrm{mg}$ of vitamin $\mathrm{B}_{12}$ had increased secretion of ECM. Thus, the objective of this study was to determine if Co supplementation during the dry period and early lactation of dairy cows would affect serum $B_{12}$ concentrations and milk production.

\section{MATERIALS AND METHODS}

The Institutional Animal Care and Use Committee of Washington State University approved the protocol.

Multiparous Holstein cows $(\mathrm{n}=36), 55 \mathrm{~d}$ before their expected calving date, were assigned to prepartum diets of $70 \%$ grass hay, $22 \%$ concentrate, and $8 \%$ alfalfa haylage (DM basis). Cows were individually fed via Calan feeding gates (American Calan, Inc., Northwood, NH). The concentrate was composed of $82.25 \%$ ground corn, $7.9 \%$ soybean meal (44\% CP), $4 \%$ molasses, $1.9 \%$ ammonia chloride, $1.5 \%$ iodized salt, $1.0 \%$ trace mineral premix (Table 1 ), $0.5 \%$ limestone, $0.20 \% \mathrm{Mg}$ oxide, $0.4 \% \mathrm{Se}$ premix $(200 \mathrm{mg} / \mathrm{kg}$ of Se as Na selenite), $0.1 \%$ vitamin A premix $(30,000 \mathrm{IU} / \mathrm{g}), 0.1 \%$ vitamin $\mathrm{D}$ premix $(8,810$ $\mathrm{IU} / \mathrm{g}), 0.1 \%$ vitamin $\mathrm{E}$ premix $(500 \mathrm{IU} / \mathrm{g})$, and $0.05 \%$ 
Table 1. Trace mineral premixes for dry cow concentrates

\begin{tabular}{|c|c|c|c|}
\hline Ingredient & $\begin{array}{l}\text { Low } \\
\text { Co }\end{array}$ & $\begin{array}{l}\text { Medium } \\
\text { Co }\end{array}$ & $\begin{array}{c}\text { High } \\
\text { Co }\end{array}$ \\
\hline & & $\%$ of salt mi & \\
\hline Iodized salt & 72.29 & 70.79 & 69.29 \\
\hline Zinc methionine $^{1}$ & 10.90 & 10.90 & 10.90 \\
\hline Zinc sulfate $^{2}$ & 3.67 & 3.67 & 3.67 \\
\hline Copper lysine ${ }^{3}$ & 3.79 & 3.79 & 3.79 \\
\hline Copper sulfate ${ }^{4}$ & 0.30 & 0.30 & 0.30 \\
\hline Manganese methionine ${ }^{5}$ & 7.58 & 7.58 & 7.58 \\
\hline Manganese oxide ${ }^{6}$ & 1.47 & 1.47 & 1.47 \\
\hline Cobalt glucoheptanate $^{7}$ & 0 & 1.5 & 3.0 \\
\hline Total & 100 & 100 & 100 \\
\hline
\end{tabular}

${ }^{1} 10 \%$ Zn (Zinpro Corp., Eden Prairie, MN).

${ }^{2} 36.4 \% \mathrm{Zn}$.

${ }^{3} 10 \% \mathrm{Cu}$ (Zinpro Corp.)

${ }^{4} 25 \% \mathrm{Cu}$

${ }^{5} 8 \%$ Mn (Zinpro Corp.).

${ }^{6} 72 \% \mathrm{Mn}$.

${ }^{7} 2.5 \%$ Co (Zinpro Corp.).

pellet binder. The concentrations of Co (DM basis) in the treatment dry cow diets were $0.15,0.89$, and 1.71 ppm (Table 2).

Subsequent to parturition, cows remained assigned to their respective treatments of low, medium, and high Co treatments until 120 DIM. The concentrations of Co for the 3 postpartum dietary treatments were $0.19,0.57$, and $0.93 \mathrm{mg} / \mathrm{kg}$ of $\mathrm{Co}$, respectively. The lactating cows were individually fed a TMR (Table 3) via Calan feeding gates, and daily feed intakes were measured. The chemical composition of the TMR is given in Table 4.

Daily DMI was recorded for all cows, and samples of the TMR were taken weekly and composited by month. Cow BW was measured on $d-55,-20,7$, and 120 relative to parturition. A sample of colostrum was collected from a nonsuckled teat after the cow was observed to have calved. Milk yields were recorded daily, and samples of a.m. and p.m. milk were taken monthly for analysis via an infrared spectrophotometer (Bentley 2000;

Table 2. Chemical composition of TMR fed to prepartum cows ${ }^{1}$

\begin{tabular}{lccc}
\hline & \multicolumn{3}{c}{ Treatment } \\
\cline { 2 - 4 } Composition & $\begin{array}{c}\text { Low } \\
\text { Co }\end{array}$ & $\begin{array}{c}\text { Medium } \\
\text { Co }\end{array}$ & $\begin{array}{c}\text { High } \\
\text { Co }\end{array}$ \\
\hline $\mathrm{CP}, \%$ & 15.0 & 14.2 & 14.8 \\
$\mathrm{NDF}, \%$ & 47 & 49 & 49 \\
$\mathrm{ADF}, \%$ & 27 & 28 & 28 \\
$\mathrm{Ca}, \%$ & 0.68 & 0.65 & 0.64 \\
$\mathrm{Co}, \mathrm{mg} / \mathrm{kg}$ & 0.15 & 0.89 & 1.71 \\
$\mathrm{Zn}, \mathrm{mg} / \mathrm{kg}$ & 73 & 62 & 68 \\
$\mathrm{Cu}, \mathrm{mg} / \mathrm{kg}$ & 15 & 11 & 13 \\
$\mathrm{Fe}, \mathrm{mg} / \mathrm{kg}$ & 185 & 208 & 606 \\
$\mathrm{Mn}, \mathrm{mg} / \mathrm{kg}$ & 68 & 80 &
\end{tabular}

${ }^{1}$ By analysis, DM basis.
Table 3. Composition of TMR for lactating cows

\begin{tabular}{lc}
\hline Ingredient & $\%$, DM basis \\
\hline Alfalfa haylage & 25.62 \\
Alfalfa hay & 22.28 \\
Concentrate $^{1}$ & 35.65 \\
Wheat mill run & 6.57 \\
Cottonseeds, whole & 9.88 \\
\hline
\end{tabular}

${ }^{1}$ The ingredient composition of the concentrate was $44.13 \%$ corn, $30 \%$ barley, $8.0 \%$ peas, $4.5 \%$ soybean meal $(44 \% \mathrm{CP}), 4.0 \%$ corn gluten meal, $2.5 \%$ molasses, $0.5 \%$ animal fat, $0.8 \%$ limestone, $1.5 \%$ iodized salt, $2.5 \%$ sodium bicarbonate, $0.6 \%$ trace mineral premix (the trace mineral premix contained $0,0.92$, and $1.84 \%$ Co glucoheptonate; other ingredients were $1.5 \% \mathrm{Cu}$ sulfate, $2.35 \% \mathrm{Cu}$ lysine, $2.33 \% \mathrm{Mn}$ methionine, $2.75 \% \mathrm{Mn}$ oxide, $6.60 \% \mathrm{Zn}$ sulfate, $6.65 \% \mathrm{Zn}$ methionine, and the remainder was iodized salt, 75.98 to $77.82 \%), 0.4 \% \mathrm{Mg}$ oxide, $0.4 \%$ Se premix $(200 \mathrm{mg} / \mathrm{kg} \mathrm{Se}), 0.05 \%$ vitamin A premix (30,000 IU/ g), $0.05 \%$ vitamin D premix (8,810 IU/g), $0.02 \%$ vitamin $\mathrm{E}$ premix $(500 \mathrm{IU} / \mathrm{g})$, and $0.05 \%$ pellet binder.

Bentley Instruments, Chaska, MN; AOAC, 1990) of major components by the regional DHIA laboratory (Burlington, WA). Individual milk samples for Co and vitamin $B_{12}$ analyses were collected on d 120 . Blood samples were collected on $\mathrm{d}-55,-20,7$, and 120 relative to parturition. Samples of serum, colostrum, and milk were frozen until analysis. Percutaneous liver biopsies were obtained under local anesthesia ( $5 \mathrm{mg}$ of lidocaine and $50 \mathrm{mg}$ of flunixine meglumine) at $-55,7$, and 120 DIM between the 9th and 10th intercostal space using a 15-cm Tru-Cut biopsy needle (Tranvenol Labs, Deerfield, IL). Biopsy specimens were transferred to a tared vial and reweighed. The samples were stored at $-30^{\circ} \mathrm{C}$ until analysis.

\section{Analyses}

Composite feed samples were dried $\left(60^{\circ} \mathrm{C}\right.$ for $\left.48 \mathrm{~h}\right)$, ground to pass a 2-mm screen (Wiley mill; Arthur H. Thomas Co., Philadelphia, PA), subsampled, then reground to pass through a $1-\mathrm{mm}$ screen, subsampled

Table 4. Chemical composition of TMR for lactating cows ${ }^{1,2}$

\begin{tabular}{lccc}
\hline & \multicolumn{3}{c}{ Treatment } \\
\cline { 2 - 4 } Composition & Low & Medium & High \\
Co & Co & 19.6 \\
\hline $\mathrm{CP}, \%$ & 19.7 & 19.8 & 35.2 \\
$\mathrm{NDF}, \%$ & 34.9 & 35.3 & 21.2 \\
$\mathrm{ADF}, \%$ & 21.2 & 21.1 & 0.74 \\
$\mathrm{Ca}, \%$ & 0.74 & 0.66 & 0.93 \\
$\mathrm{Co}, \mathrm{mg} / \mathrm{kg}$ & 0.19 & 0.57 & 93 \\
$\mathrm{Zn}, \mathrm{mg} / \mathrm{kg}$ & 99 & 85 & 13.7 \\
$\mathrm{Cu}, \mathrm{mg} / \mathrm{kg}$ & 13.6 & 13.8 & 150 \\
$\mathrm{Fe}, \mathrm{mg} / \mathrm{kg}$ & 120 & 150 & 74 \\
$\mathrm{Mn}, \mathrm{mg} / \mathrm{kg}$ & 58 & 76 & \\
\hline
\end{tabular}

${ }^{1}$ By analysis, DM basis.

${ }^{2} \mathrm{NE}_{\mathrm{L}}=1.572 \mathrm{Mcal} / \mathrm{kg}$ (calculated from NRC, 2001). 
Table 5. Effect (least squares means) of dietary Co supplementation on BW, feed intake, and yield of milk and milk components in lactating dairy cows

\begin{tabular}{|c|c|c|c|c|c|c|c|}
\hline \multirow[b]{2}{*}{ Measure } & \multicolumn{3}{|c|}{ Treatment (Trt) } & \multirow[b]{2}{*}{ SEM } & \multicolumn{3}{|c|}{$\begin{array}{l}\text { Type II SS } P>F \text { for main } \\
\text { comparison and interaction }\end{array}$} \\
\hline & $\begin{array}{l}\text { Low } \\
\text { Co }\end{array}$ & $\begin{array}{l}\text { Medium } \\
\text { Co }\end{array}$ & $\begin{array}{l}\text { High } \\
\text { Co }\end{array}$ & & Trt & Time & $\begin{array}{l}\text { Trt } \times \\
\text { time }\end{array}$ \\
\hline DMI, kg/d & 27.1 & 27.4 & 25.1 & 0.90 & $\mathrm{NS}$ & 0.01 & 0.01 \\
\hline Milk yield, kg/d & 42.9 & 43.6 & 43.6 & 0.30 & NS & 0.05 & 0.01 \\
\hline $3.5 \%$ FCM, kg/d & 44.7 & 43.8 & 46.4 & 1.00 & NS & 0.01 & 0.01 \\
\hline $\mathrm{ECM}, \mathrm{kg} / \mathrm{d}$ & 43.6 & 43.5 & 45.2 & 1.13 & NS & 0.01 & 0.01 \\
\hline Fat, $\mathrm{kg} / \mathrm{d}$ & 1.61 & 1.54 & 1.68 & 0.05 & NS & 0.01 & 0.01 \\
\hline Protein, kg/d & 1.20 & 1.29 & 1.25 & 0.025 & NS & 0.01 & 0.01 \\
\hline Fat, \% & 3.81 & 3.54 & 3.91 & 0.12 & NS & 0.01 & 0.01 \\
\hline Protein, \% & 2.82 & 2.97 & 2.90 & 0.15 & NS & NS & 0.06 \\
\hline FCM/DMI & 1.81 & 1.78 & 1.92 & 0.123 & $\mathrm{NS}$ & 0.01 & 0.01 \\
\hline ECM/DMI & 1.76 & 1.76 & 1.87 & 0.116 & $\mathrm{NS}$ & 0.01 & 0.01 \\
\hline $\mathrm{ME} / \mathrm{IE}^{1}$ & 0.766 & 0.766 & 0.813 & 0.051 & $\mathrm{NS}$ & 0.01 & 0.01 \\
\hline
\end{tabular}

${ }^{1} \mathrm{ME} / \mathrm{IE}=$ milk energy $(\mathrm{Mcal})$ divided by intake energy $\left(\mathrm{Mcal}\right.$ of $\left.\mathrm{NE}_{\mathrm{L}}\right)$.

again, and stored at $-20^{\circ} \mathrm{C}$ until further analysis. Feed analysis consisted of $\mathrm{DM}$ at $100^{\circ} \mathrm{C}(\mathrm{AOAC}, 1990), \mathrm{CP}$ by an automated nitrogen analyzer (Leco FP-528, Leco Corp., St. Joseph, MI), and NDF and ADF using an Ankom 200 Fiber Analyzer (Ankom Technologies, Fairfield, NY). Blood, liver, colostrum, and milk samples were analyzed for Co by neutron activation analysis $\left({ }^{60} \mathrm{Co}\right.$ with a half-life of $5.27 \mathrm{yr}$ using a multichannel analyzer; Ametek Inc., Paoli, PA) at the Washington State University's Nuclear Reactor Center. Copper, Ca, $\mathrm{Zn}, \mathrm{Cu}, \mathrm{Mn}$, and $\mathrm{Fe}$, and $\mathrm{Co}$ in feeds were determined by atomic absorption spectrophotometry (Robinson, 1975). Nonesterified fatty acids were determined using a commercial kit (NEFA-C, Wako Chemical GmbH, Neuss, Germany). Vitamin $\mathrm{B}_{12}$ analyses were performed by RIA (Dualcount, Diagnostic Products Co., Los Angeles, CA), which was modified so proteins were denatured by heating samples in a boiling water bath for $15 \mathrm{~min}$ instead of incubating at $37^{\circ} \mathrm{C}$ for $30 \mathrm{~min}$.

\section{Statistical Analysis}

Data were analyzed by GLM of PROC MIXED procedures for a completely randomized design with repeated measures (SAS Institute, 2001). The cows were blocked according to expecting calving date, and treatment assignments were rotated among cows within a block. The analysis of all time series data was performed using the model:

$$
\mathrm{Y}_{\mathrm{ijk}}=\mu+\alpha_{\mathrm{i}}+\beta_{\mathrm{j}}+(\alpha \beta)_{\mathrm{ij}}+\delta_{\mathrm{k}}\left(\alpha_{\mathrm{i}} \beta_{\mathrm{j}}\right)+\mathrm{e}_{\mathrm{ijk}}
$$

where $Y_{\mathrm{ijk}}=$ dependent variable, $\mu$ = dependent variable mean, $\alpha_{\mathrm{i}}=$ effect of treatment $\mathrm{i}\left(\mathrm{i}=1\right.$ to 3 ), $\beta_{\mathrm{j}}=$ effect of sampling at week $\mathrm{j}(\mathrm{j}=1$ to 17$),(\alpha \beta)_{\mathrm{ij}}=$ interaction effect between treatment and sampling week, $\delta_{\mathrm{k}}\left(\alpha_{\mathrm{i}} \beta_{\mathrm{j}}\right)=$ random effect of cow, and $\mathrm{e}_{\mathrm{ijk}}=$ residual error term. Statistical significance was declared at $P<0.05$, and trends for treatment effects were declared at $P>0.05$ and $P<0.15$.

\section{RESULTS AND DISCUSSION}

\section{Effects on Performance}

The initial average BW of cows during the study was $677 \pm 70 \mathrm{~kg}$. Because initial BW was not considered when assigning cows to treatment, cows assigned to the medium Co treatment weighed an average of $36 \mathrm{~kg}$ less. During the dry period, initial DMI were less than expected primarily because cows were adapting to the Calan feeding gates. Mean DMI was 16.0, 15.2, and $14.3 \mathrm{~kg} / \mathrm{d}(\mathrm{SE}=0.93)$, respectively, for the low, medium, and high Co diets. There was no effect $(P>0.15)$ of treatment on prepartum DMI.

Changes in BW of the lactating cows were not affected $(P>0.15)$ by dietary treatment. Similarly, DMI of the lactating cows was not affected $(P>0.15)$ by Co intake (Table 5). There was a week by treatment interaction for DMI during lactation whereby cows fed the high Co diet consumed less DM in the first 5 wk postpartum than cows fed the medium Co diet (Figure 1). Daily intakes of Co increased as daily DMI increased with time. For example, Co intakes of the lactating cows were $2.7,8.3$, and $10.3 \mathrm{mg}$ of $\mathrm{Co} / \mathrm{d}$ for wk 1 postpartum, but $4.9,15.8$, and $25.6 \mathrm{mg}$ of Co/d for wk 18 postpartum for the low, medium, and high Co treatments, respectively.

There was no effect of treatment $(P>0.15)$ on milk composition or yields of milk, milk components, ECM, $3.5 \%$ FCM, or feed efficiency (Table 5). Efficiency of milk production (ECM/DMI) decreased with the pro- 


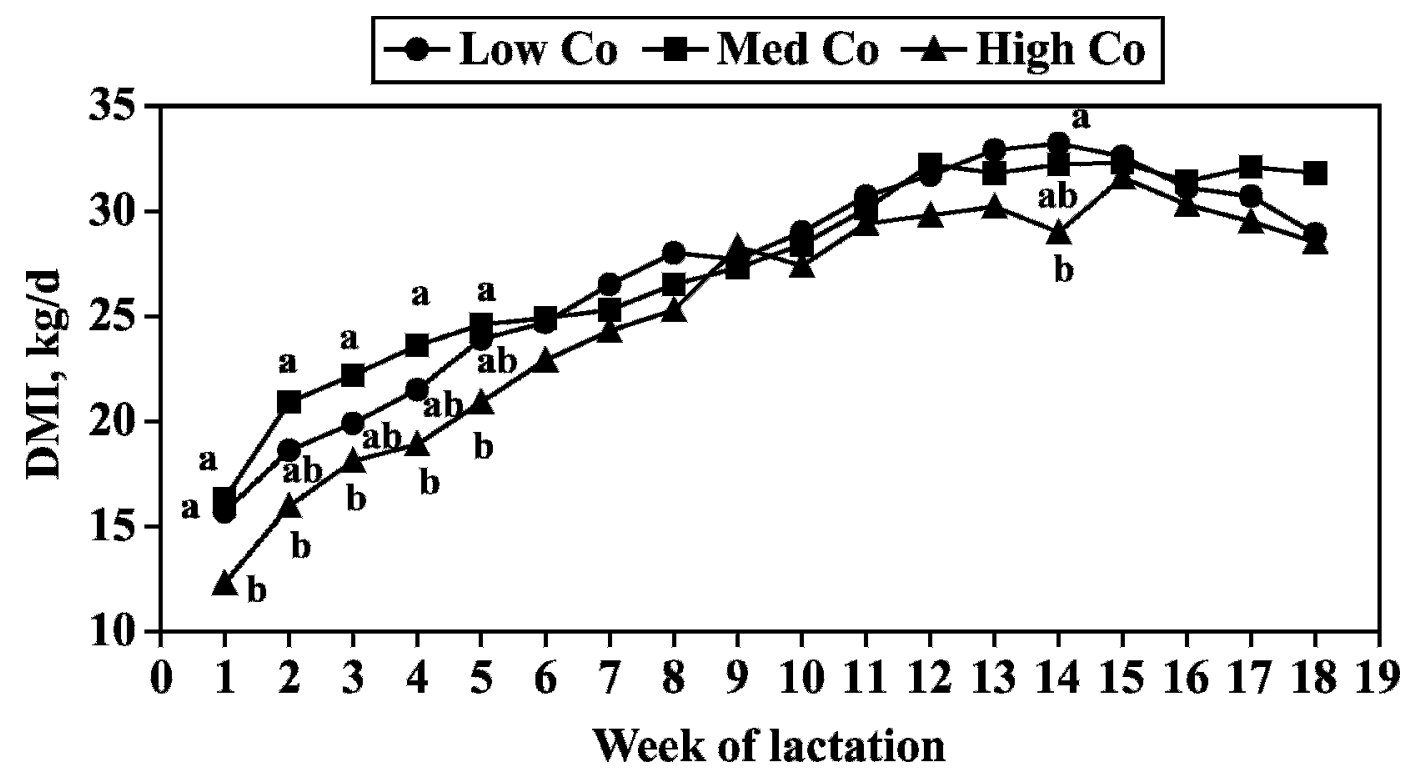

Figure 1. Effect of dietary Co on DMI of lactating cows. ${ }^{\text {a,b }}$ Weekly treatment means with different letters differ, $P<0.05$.

gression of lactation (week by treatment interaction, $P$ $>0.05$; Table 5; Figure 2) presumably due to increased BW gain. As expected, the trends (not shown) for FCM per DMI and ME per energy intake were similar to that for ECM per DMI.

Girard and Matte (2005) injected cows with $10 \mathrm{mg}$ of vitamin $\mathrm{B}_{12}$ every week and obtained increased yield of milk components and ECM. Croom et al. (1981) did not find an effect on milk fat percentage when cows were injected weekly with $150 \mathrm{mg}$ of vitamin $\mathrm{B}_{12}$; however, that study was only for $21 \mathrm{~d}$ of early lactation.
Previously, Kincaid et al. (2003) reported a 3-way interaction of time $\times$ treatment $\times$ parity with higher milk response to Co supplementation of multiparous cows.

\section{Effects on Tissue Co and $B_{12}$}

Concentrations of Co in serum were not affected by Co intake or week of parity (Tables 6 and 7). Although concentrations of vitamin $\mathrm{B}_{12}$ in serum were not affected by Co intake (Table 6), there was a large decrease in serum $\mathrm{B}_{12}$ from 55 to $20 \mathrm{~d}$ prepartum, and a much

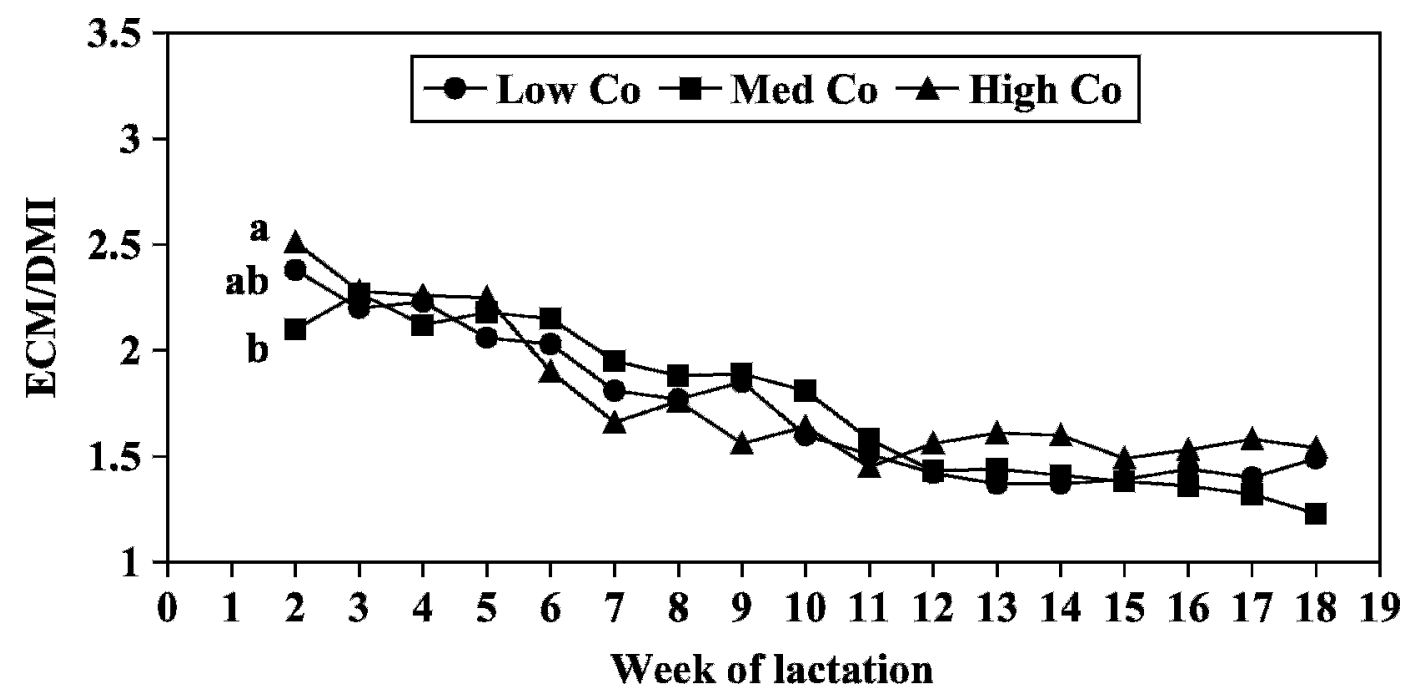

Figure 2. Effect of Co intake on efficiency of milk production (ECM/DMI), ${ }^{a, b}$ Weekly treatment means with different letters differ, $P<$ 0.05. Standard errors were $0.0966,0.1008$, and 0.1116 for low, medium, and high levels of Co supplementation, respectively. 
Table 6. Effect of dietary Co supplementation on selected measures in serum and liver of lactating cows

\begin{tabular}{|c|c|c|c|c|c|c|c|}
\hline \multirow[b]{2}{*}{ Measure } & \multicolumn{3}{|c|}{ Treatment (Trt) } & \multirow[b]{2}{*}{ SEM } & \multicolumn{3}{|c|}{$\begin{array}{l}\text { Type II SS } P>F \text { for main } \\
\text { comparison and interaction }\end{array}$} \\
\hline & $\begin{array}{l}\text { Low } \\
\text { Co }\end{array}$ & $\begin{array}{l}\text { Medium } \\
\text { Co }\end{array}$ & $\begin{array}{c}\text { High } \\
\text { Co }\end{array}$ & & Trt & Week & $\begin{array}{l}\text { Trt } \times \\
\text { week }\end{array}$ \\
\hline \multicolumn{8}{|l|}{ Serum } \\
\hline $\mathrm{Co}, \mathrm{mg} / \mathrm{kg}$ & 0.207 & 0.210 & 0.196 & 0.023 & NS & NS & 0.03 \\
\hline $\mathrm{Cu}, \mathrm{mg} / \mathrm{kg}$ & 0.63 & 0.64 & 0.62 & 0.05 & NS & 0.01 & NS \\
\hline $\mathrm{Zn}, \mathrm{mg} / \mathrm{kg}$ & 1.25 & 1.29 & 1.16 & 0.12 & NS & 0.01 & NS \\
\hline $\mathrm{B}_{12}, \mathrm{pg} / \mathrm{mL}$ & 327 & 275 & 304 & 55 & NS & 0.01 & NS \\
\hline NEFA, mEq/L & 286 & 219 & 268 & 7.7 & NS & 0.01 & NS \\
\hline $\mathrm{IgG}, \mathrm{mg} / \mathrm{dL}$ & 2,882 & 2,986 & 3,104 & 288 & NS & 0.05 & NS \\
\hline IgM, mg/dL & 208 & 193 & 176 & 31 & NS & NS & NS \\
\hline \multicolumn{8}{|l|}{ Liver } \\
\hline $\mathrm{Co}, \mathrm{mg} / \mathrm{kg}$ & 1.90 & 1.94 & 2.00 & 0.19 & NS & NS & NS \\
\hline
\end{tabular}

smaller decrease from $7 \mathrm{~d}$ postpartum until $120 \mathrm{~d}$ postpartum (Table 7; Figure 3). To our knowledge, this is the first report of serum $B_{12}$ concentrations declining during late pregnancy in cows. A combination of lowered DMI in the early dry period and increased transfer of $\mathrm{B}_{12}$ to the growing fetus may account for the lower serum $\mathrm{B}_{12}$ at $20 \mathrm{~d}$ prepartum compared with $55 \mathrm{~d}$ prepartum. Although we did not measure DMI of cows before the start of the study, total ruminal synthesis of $\mathrm{B}_{12}$ probably was greater before dry-off because of larger DMI in cows during late lactation compared with the nonlactating, late gestation period. Some of the decline in maternal serum $\mathrm{B}_{12}$ concentration during late pregnancy undoubtedly reflects maternal transfer of $\mathrm{B}_{12}$ to the rapidly growing fetus. Elliot et al. (1965) reported that blood $\mathrm{B}_{12}$ concentrations during early lactation were $23 \%$ below those at mid lactation in dairy cows. Girard and Matte (1999) also found serum $\mathrm{B}_{12}$ to be lowest during the first 2 mo of lactation. Judson et al. (1997) found that Co supplemented as an intraruminal pellet increased $\mathrm{B}_{12}$ concentrations in plasma, liver, and milk. They suggested that milk $B_{12}$ concentration might be a useful indictor of effectiveness of Co supplementa- tion-a better indicator than plasma $\mathrm{B}_{12}$. The concentrations of vitamin $\mathrm{B}_{12}$ in colostrum and milk tended $(P=0.11$ and 0.16 , respectively) to be increased by dietary Co supplementation (Table 8). Thus, dietary Co supplementation likely increased ruminal synthesis of vitamin $B_{12}$ even though serum $B_{12}$ concentrations were not affected. Possibly, the maternal transfer of $B_{12}$ from blood to the fetus, colostrum, and milk prevented increased ruminal $B_{12}$ synthesis from being reflected in serum $\mathrm{B}_{12}$ concentrations in cows.

Despite liver having the highest Co concentration and being the main storage site for Co (Underwood and Suttle, 1999), liver Co concentration was not affected by either Co intake or day of sampling ( -55 and $120 \mathrm{~d}$ postpartum; Tables 6 and 7). Similarly, Kincaid et al. (2003) previously reported that supplementing diets of lactating and nonlactating cows with Co did not increase liver Co concentrations.

Although the concentration of Co in colostrum was not affected by Co intake, the concentration of Co in milk was increased by Co supplementation (Table 8). The elevated concentration of Co in milk of Co-supplemented cows indicates that intestinal Co absorption

Table 7. Effect of DIM on selected measures in serum and liver of lactating cows

\begin{tabular}{|c|c|c|c|c|c|c|}
\hline \multirow[b]{2}{*}{ Measure } & \multicolumn{4}{|c|}{ DIM (relative to parturition) } & \multirow[b]{2}{*}{ SEM } & \multirow[b]{2}{*}{$P<$} \\
\hline & -55 & -20 & 7 & 120 & & \\
\hline \multicolumn{7}{|l|}{ Serum } \\
\hline NEFA, $\mathrm{mEq} / \mathrm{L}$ & 173 & 118 & 619 & 121 & 7.7 & 0.01 \\
\hline $\mathrm{Co}, \mu \mathrm{g} / \mathrm{mL}$ & 0.196 & 0.205 & 0.210 & 0.208 & 0.023 & NS \\
\hline $\mathrm{B}_{12}, \mathrm{pg} / \mathrm{mL}$ & 576 & 230 & 205 & 196 & 55 & 0.001 \\
\hline $\mathrm{Zn}, \mu \mathrm{g} / \mathrm{mL}$ & 1.39 & 1.20 & 1.13 & 1.20 & 0.12 & 0.01 \\
\hline $\mathrm{Cu}, \mu \mathrm{g} / \mathrm{mL}$ & 0.68 & 0.55 & 0.70 & 0.59 & 0.05 & 0.01 \\
\hline $\mathrm{IgG}, \mathrm{mg} / \mathrm{dL}$ & 2,970 & 2,872 & 2,805 & 3,314 & 288 & 0.05 \\
\hline IgM, mg/dL & 200 & 205 & 170 & 194 & 31 & NS \\
\hline \multicolumn{7}{|l|}{ Liver } \\
\hline $\mathrm{Co}, \mu \mathrm{g} / \mathrm{g}$ & 1.84 & $\mathrm{NA}^{1}$ & 2.19 & 1.83 & 0.19 & NS \\
\hline
\end{tabular}

\footnotetext{
${ }^{1} \mathrm{NA}=$ not analyzed.
} 
Table 8. Effect of dietary Co supplementation on selected measures in colostrum and milk

\begin{tabular}{|c|c|c|c|c|c|}
\hline \multirow[b]{2}{*}{ Measure } & \multicolumn{3}{|c|}{ Treatment } & \multirow[b]{2}{*}{ SEM } & \multirow[b]{2}{*}{$\begin{array}{c}P \\
\text { Treatment }\end{array}$} \\
\hline & $\begin{array}{l}\text { Low } \\
\text { Co }\end{array}$ & $\begin{array}{l}\text { Medium } \\
\text { Co }\end{array}$ & $\begin{array}{c}\text { High } \\
\text { Co }\end{array}$ & & \\
\hline \multicolumn{6}{|l|}{ Colostrum } \\
\hline $\mathrm{B}_{12}, \mathrm{pg} / \mathrm{mL}$ & 30,167 & 40,722 & 38,324 & 3,492 & 0.11 \\
\hline $\mathrm{Co}, \mu \mathrm{g} / \mathrm{mL}$ & 0.128 & 0.144 & 0.095 & 0.055 & NS \\
\hline $\mathrm{IgG}, \mathrm{mg} / \mathrm{dL}$ & 3,725 & 5,937 & 5,655 & 490 & NS \\
\hline $\mathrm{IgM}, \mathrm{mg} / \mathrm{dL}$ & 139 & 188 & 182 & 16 & NS \\
\hline \multicolumn{6}{|l|}{ Milk } \\
\hline $\mathrm{B}_{10}, \mathrm{pg} / \mathrm{mL}$ & 3,369 & 4,497 & 4,224 & 464 & 0.16 \\
\hline $\mathrm{Co}, \mu \mathrm{g} / \mathrm{mL}$ & 0.089 & 0.120 & 0.130 & 0.0069 & 0.038 \\
\hline
\end{tabular}

likely was greater in these cows even though Co concentrations in serum and liver were not affected. The concentrations of $\mathrm{Cu}, \mathrm{Zn}, \mathrm{NEFA}, \mathrm{IgG}$, and IgM in serum were not affected by Co intakes; however, concentrations of $\mathrm{Cu}, \mathrm{Zn}, \mathrm{NEFA}$, and IgG in serum were affected by week of sampling (Table 7). Other measures affected by week of lactation were concentrations of NEFA and IgG in serum (Table 7). In colostrum, neither IgG nor IgM concentration was affected by Co intake of cows.

\section{CONCLUSIONS}

Fetal growth during late gestation and milk synthesis are major drains on maternal reserves of vitamin $B_{12}$. Likewise, lowered DMI of nonlactating cows compared with lactating cows probably results in reduced ruminal synthesis of vitamin $\mathrm{B}_{12}$. Accordingly, serum $\mathrm{B}_{12}$ concentrations declined sharply between d 55 and 20 prepartum, and remained low during early lactation. Although serum $\mathrm{B}_{12}$ was unchanged, added dietary Co caused an increase in milk Co concentration and tended to increase vitamin $\mathrm{B}_{12}$ in colostrum and milk. Numerous factors such as grain source, forage-to-concentrate

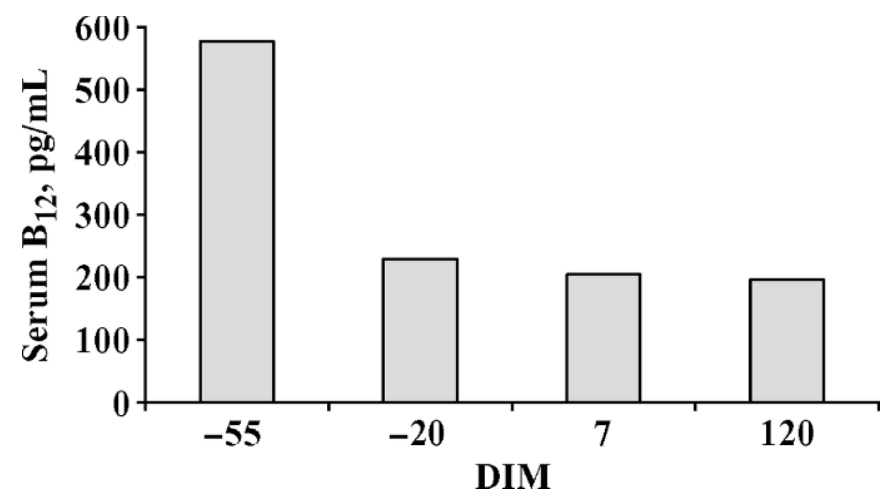

Figure 3. Changes in serum vitamin $B_{12}$ concentrations during the dry period and early lactation. Concentrations of $\mathrm{B}_{12}$ in serum declined significantly $(P<0.001)$ with time. Standard errors were $27,26,26$, and 26 for $\mathrm{d}-55,-20,7$, and 120 , respectively. ratio, Co intake, and total DMI may affect ruminal synthesis of vitamin $\mathrm{B}_{12}$.

\section{REFERENCES}

AOAC. 1990. Official Methods of Analysis. Vol. 1. 15th ed. Association of Official Analytical Chemists, Arlington, VA.

Croom, W. J., Jr., A. H. Rakes, A. C. Linnerud, G. A. Ducharme, and J. M. Elliot. 1981. Vitamin $\mathrm{B}_{12}$ administration for milk fat synthesis in lactating dairy cows fed a low fiber diet. J. Dairy Sci. 64:1555-1560.

Elliot, J. M., D. E. Hogue, and H. F. Tyrrell. 1965. Blood vitamin $B_{12}$ status of the dairy cow in late pregnancy and early lactation. J. Dairy Sci. 48:1335-1338.

Girard, C. L., and J. J. Matte. 1999. Changes in serum concentrations of folates, pyridoxal, pyridoxal-5-phosphate and vitamin $\mathrm{B}_{12}$ during lactation of dairy cows fed dietary supplements of folic acid. Can. J. Anim. Sci. 79:107-113.

Girard, C. L., and J. J. Matte. 2005. Effects of intramuscular injections of vitamin $\mathrm{B}_{12}$ on lactation performance of dairy cows fed dietary supplements of folic acid and rumen-protected methionine. J. Dairy Sci. 88:671-676.

Judson, G. J., J. D. McFarlane, A. Mitsioulis, and P. Zviedrans. 1997. Vitamin $\mathrm{B}_{12}$ responses to cobalt pellets in beef cows. Aust. Vet. J. 75:660-662.

Kincaid, R. L., L. E. Lefebvre, J. D. Cronrath, M. T. Socha, and A. B. Johnson. 2003. Effect of dietary cobalt supplementation on cobalt metabolism and performance of dairy cattle. J. Dairy Sci. 86:1405-1414.

Looney, J. W., G. Gille, R. L. Preston, E. R. Graham, and W. H. Pfander. 1976. Effects of plant species and cobalt intake upon cobalt utilization and ration digestibility by sheep. J. Anim. Sci. 42:693-698.

Mills, C. F. 1981. Cobalt defciency and cobalt requirements of ruminants. Pages 129-140 in Recent Advances in Animal Nutrition. W. Haresign, ed. Butterworths, Boston, MA.

National Research Council. 2001. Nutrient Requirements of Dairy Cattle. 7th rev. ed. Natl. Acad. Sci., Washington, DC.

Robinson, J. W. 1975. Atomic Absorption Spectroscopy. 2nd ed. Marcel Dekker, Inc., New York, NY.

SAS Institute. 2001. SAS User's Guide. Version 8.1. 1st ed. SAS Institute Inc., Cary, NC.

Stangl, G. I., F. J. Schwarz, B. Jahn, and M. Kirchgessner. 2000a. Cobalt-deficiency-induced hyperhomocysteinaemia and oxidative status of cattle. Br. J. Nutr. 83:3-6.

Stangl, G. I., F. J. Schwarz, H. Müller, and M. Kirchgessner. 2000b. Evaluation of the cobalt requirement of beef cattle based on vitamin $\mathrm{B}_{12}$, folate, homocysteine and methylmalonic acid. Br. J. Nutr. 84:645-653.

Tiffany, M. E., V. Fellner, and J. W. Spears. 2006. Influence of cobalt concentrations on vitamin $\mathrm{B}_{12}$ production and fermentation of mixed microorganisms grown in continuous culture flow-through fermentors. J. Anim. Sci. 84:635-640. 
Tiffany, M. E., and J. W. Spears. 2005. Differential responses to dietary cobalt in finishing steers fed corn- versus barley-based diets. J. Anim. Sci. 83:2580-2589.

Tiffany, M. E., and J. W. Spears. 2002. Effects of dietary cobalt source and concentration on performance, vitamin $\mathrm{B}_{12}$ status, and ruminal and plasma metabolites in growing and finishing steers. J. Anim. Sci. 80(Suppl. 1):47. (Abstr.)

Tiffany, M. E., J. W. Spears, L. Xi, and J. Horton. 2003. Influence of dietary cobalt source and concentration on performance, vitamin
$\mathrm{B}_{12}$ status, and ruminal plasma metabolites in growing and finishing steers. J. Anim. Sci. 81:3151-3159.

Underwood, E. J., and N. F. Suttle. 1999. Cobalt. Pages 251-282 in The Mineral Nutrition of Livestock. CABI Publishing, New York, NY.

Walker, C. K., and J. M. Elliot. 1972. Lactational trends in vitamin $\mathrm{B}_{12}$ status on conventional and restricted-roughage rations. J. Dairy Sci. 55:474-479.

Wilson, K. A., J. M. Elliot, and M. M. Mathias. 1967. Liver vitamin $\mathrm{B}_{12}$ status of the lactating dairy cow. J. Dairy Sci. 50:1280-1282. 